Environmental Pollution

November 2018, Volume 242, Part B, Pages 1226-1235

http://dx.doi.org/10.1016/i.envpol.2018.08.020

http://archimer.ifremer.fr/doc/00453/56419/

(c) 2018 Elsevier Ltd. All rights reserved.

\title{
Nanoplastics impaired oyster free living stages, gametes and embryos
}

Tallec Kevin ${ }^{1,}{ }^{\text {, }}$, Huvet Arnaud ${ }^{1}$, Di Poi Carole ${ }^{1}$, González-Fernández Carmen ${ }^{2}$, Lambert Christophe ${ }^{2}$, Petton Bruno ${ }^{1}$, Le Goïc Nelly ${ }^{2}$, Berchel Mathieu ${ }^{3}$, Soudant Philippe ${ }^{2}$, Paul-Pont Ika ${ }^{2}$

${ }^{1}$ Ifremer, Laboratoire des Sciences de l'Environnement Marin (LEMAR), UMR 6539 UBO/CNRS/IRD/Ifremer, CS 10070, 29280, Plouzané, France

${ }^{2}$ Laboratoire des Sciences de l'Environnement Marin (LEMAR), UMR 6539 CNRS/UBO/IRD/Ifremer Institut Universitaire Européen de la Mer, Technopôle Brest-Iroise - Rue Dumont d'Urville, 29280, Plouzané, France

${ }^{3}$ Université de Brest, Université Européenne de Bretagne, CNRS UMR 6521, CEMCA, IFR 148

ScInBios, 6 Avenue Victor Le Gorgeu, 29238, Brest, France

*Corresponding author : Kevin Tallec, email address : kevin.tallec@univ-brest.fr

\begin{abstract}
:
In the marine environment, most bivalve species base their reproduction on external fertilization. Hence, gametes and young stages face many threats, including exposure to plastic wastes which represent more than $80 \%$ of the debris in the oceans. Recently, evidence has been produced on the presence of nanoplastics in oceans, thus motivating new studies of their impacts on marine life. Because no information is available about their environmental concentrations, we performed dose-response exposure experiments with polystyrene particles to assess the extent of micro/nanoplastic toxicity. Effects of polystyrene with different sizes and functionalization (plain 2- $\mu \mathrm{m}, 500-\mathrm{nm}$ and $50-\mathrm{nm} ; \mathrm{COOH}-$ $50 \mathrm{~nm}$ and $\mathrm{NH} 2-50 \mathrm{~nm}$ ) were assessed on three key reproductive steps (fertilization, embryogenesis and metamorphosis) of Pacific oysters (Crassostrea gigas). Nanoplastics induced a significant decrease in fertilization success and in embryo-larval development with numerous malformations up to total developmental arrest. The $\mathrm{NH} 2-50$ beads had the strongest toxicity to both gametes (EC50 $=4.9 \mu \mathrm{g} / \mathrm{mL}$ ) and embryos $(E C 50=0.15 \mu \mathrm{g} / \mathrm{mL}$ ), showing functionalization-dependent toxicity. No effects of plain microplastics were recorded. These results highlight that exposures to nanoplastics may have deleterious effects on planktonic stages of oysters, presumably interacting with biological membranes and causing cyto/genotoxicity with potentially drastic consequences for their reproductive success.
\end{abstract}




\section{Graphical abstract}

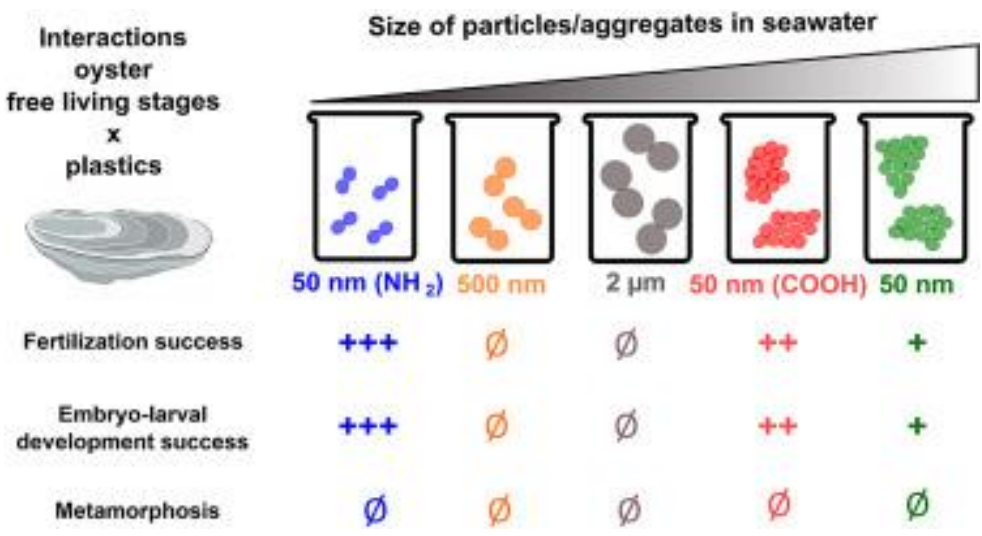

\section{Highlights}

- Oyster gametes, embryos and larvae were exposed to nano- and microplastics. Nanoplastics caused significant decrease in fertilization and embryogenesis success. Danoplastics functionalization influences their behavior and toxicity. No effect of plain microplastics was demonstrated on all endpoints.

Keywords : Oyster, Embryos, Gametes, Microplastics, Nanoplastics 
36 Mismanagement of plastic wastes is one of the major concerns of the scientific community in the

3721 st century (Galloway et al., 2017). The exponential use of plastics by human society since 1950

38 has led to a significant release of wastes into the environment (Cole et al., 2011; Geyer et al., 39 2017). Between 13,200 and 34,800 tons of plastic debris were estimated to have been introduced 40 daily into the oceans in 2010, and this amount is expected to increase by an order of magnitude 41 by 2025 (Jambeck et al., 2015). Today, plastic debris are widespread and ubiquitous in marine environments from the sea surface (Eriksen et al., 2014) to the sediment (Van Cauwenberghe et

43 al., 2015), including in remote areas such as polar regions (Cózar et al., 2017), deep-sediments 44 (Bergmann et al., 2017) and desert islands (Lavers and Bond, 2017).

Microplastics (MP) are defined as particles with a size less than $5 \mathrm{~mm}$ (Galloway et al., 2017), originating from manufactured beads/fibers (primary MP) or weathering of larger waste

47 (secondary MP). They represent the most abundant plastic items in oceans in terms of the number of particles per unit of water (>92\% of floating plastics) (Cole et al., 2011; Eriksen et al., 2014).

49 Recently, a new class of debris was described, namely nanoplastics (NP), defined as particles $50<100 \mathrm{~nm}$ (Galloway et al., 2017) or <1000 nm (Gigault et al., 2018). The definition used in the 51 present study $(<100 \mathrm{~nm})$ refers to the usual definition of nanoscale; i.e. the point where the properties of a material change (higher surface area effect and interaction with biological membranes) (Klaine et al., 2012). Their production has been demonstrated by mechanical

54 fragmentation (Lambert and Wagner, 2016), photo-degradation (Gigault et al., 2016) or 55 biodegradation (Dawson et al., 2018) of larger items. Likewise, similarly to MP, primary NP 56 from cosmetics (Hernandez et al., 2017), 3D-printing wastes (Stephens et al., 2013), lubricants 57 (Dubey et al., 2015) or drugs (Lusher et al., 2017) are suspected to enter the oceans directly. The 
58 increase of NP used in such industries - and thus their release in environment - is suspected

59 although very little information is available regarding the actual quantities used and discarded. At

60 sea, the presence of plastic particles lower than $1 \mu \mathrm{m}$ has been recently argued in the Atlantic

61 Gyre (Ter Halle et al., 2017). However, owing to a lack of methods, no or very little information

62 is currently available about the environmental concentrations of NP and small MP particles $(<100$

$63 \mu \mathrm{m}$ ), respectively (e.g. Huvet et al., 2016). Their environmental concentrations can only be

64 estimated, for example following a power-law increase (around a 2.2 factor) from sea surface

65 samples as recently proposed (Erni-Cassola et al., 2017).

66 Despite the lack of knowledge concerning MP and NP distributions in the oceans, a consensus 67 exists about the threat posed by small plastic particles for aquatic life (GESAMP, 2015). Effects 68 of MP on feeding behavior (Cole et al., 2013; Ogonowski et al., 2016), energy balance (Wright et 69 al., 2013; Watts et al., 2015), reproduction (Sussarellu et al., 2016; Gardon et al., 2018), and 70 immune system (Avio et al., 2015; Paul-Pont et al., 2016) were demonstrated and ecological 71 impacts can be discerned (Rochman et al., 2015; Green et al., 2016; Galloway et al., 2017).

72 Furthermore, at the nanoscale, specific effects are expected as result of the physico-chemical properties of NP (Mattsson et al. 2015a; da Costa et al., 2016). Nanoparticles have a much greater surface/volume ratio than microparticles - the number of surface atoms increases when size decreases - which enhances their reactivity in aquatic environments (Mattsson et al. 2015a, Rocha et al. 2015). Likewise, the risk of translocation and overall transfer into the tissues of organisms increases at the nanoscale. For instance, fluorescent nano-polystyrene beads (NP-PS; $50 \mathrm{~nm}$ ) seemed dispersed in the body of Paracyclopina nana after ingestion, while MP (500 nm and $6 \mu \mathrm{m}$ ) remained in the digestive tract with a shorter retention time (Jeong et al., 2017). Initial assessments of NP toxicity highlighted risks to survival, feeding activity, embryogenesis, the 
81 immune system, fecundity (number of offspring and/or pregnancy rate), metabolism (changes in

82 amino acid composition, liver dysfunctions and energy balance) and behavior at a wide range of trophic levels including phytoplankton (Besseling et al., 2014), echinoderms (Della Torre et al., 2014), rotifers (Jeong et al., 2016), crustaceans (Cui et al., 2017; Jeong et al., 2017), bivalves (Wegner et al., 2012 ; Canesi et al., 2016) and fish (Mattsson et al. 2015b, Mattsson et al. 2017).

In the adult Pacific oyster Crassostrea gigas (Bayne et al., 2017), polystyrene microbeads of 2 and $6 \mu \mathrm{m}$ were shown to interfere considerably with gametogenesis, in terms of quantity and quality of produced gametes, leading to undesirable effects on the performance of offspring despite no direct exposure (Sussarellu et al., 2016). Because C. gigas has external fertilization, the free-living stages (i.e. gametes, embryos and larvae) must cope with the stress occurring in estuarine and coastal marine habitats where oysters live. To date only one study has investigated the impacts of plastic debris exposure to Pacific oyster larvae using 1 and $10 \mu \mathrm{m}$ MP with no effect on their growth rate or survival (Cole and Galloway, 2015). These authors also studied the ingestion of polystyrene particles spanning $70 \mathrm{~nm}$ to $20 \mu \mathrm{m}$ in size, but no toxic endpoint was monitored following exposure to this size class. For gametes, carboxylic nanoplastics $(100 \mathrm{~nm})$ induced oxidative stress in oyster spermatozoa linked to an increase in ROS production

97 (González-Fernández et al., 2018). In this context, the present study aims to assess the potential adverse effects of plastic items on Pacific oyster free-living stages, targeting specifically the essential steps of fertilization, embryo-larval development and metamorphosis, so as to provide a 100 view over the complete life cycle in addition to the adult exposure of Sussarellu et al. (2016) (Fig.

101 1). Here, oyster gametes, embryos and larvae were exposed to five types of polystyrene particles, varying in size from NP to MP $(50 \mathrm{~nm} ; 500 \mathrm{~nm} ; 2 \mu \mathrm{m})$ and in functionalization (no functional group, or presence of carboxyl or amine groups) to examine a size effect between MP and NP 
104 (plain particles), as well as a surface properties effect between NP exhibiting different

105 functionalization. The behavior of the particles was measured in seawater using Dynamic Light

106 Scattering (DLS) to assess particle aggregation and modifications of the mean surface charge.

107 Materials and methods

108 Micro- and nanoplastic

109 Five commercially available polystyrene (PS) beads were purchased from Polysciences/Bangs

110 Laboratories and stored at $4{ }^{\circ} \mathrm{C}$ prior to experiments: 50-nm, 500-nm and 2- $\mu \mathrm{m}$ beads without

111 functionalization (Plain), and 50-nm beads coated with carboxyl (COOH-50) or amine groups

$112\left(\mathrm{NH}_{2}-50\right)$. Before each handling, particles were vortexed to prevent particle aggregation and

113 insure good suspension homogenization. Commercial suspensions were in ultrapure water (UW)

114 with Tween-20 $0^{\odot}$ surfactant $(<0.1 \%)$ to limit aggregation; Tween-20 ${ }^{\odot}$ had previously been

115 demonstrated to be innocuous for marine invertebrates at this dose (Ostroumov, 2003). Raman

116 microspectroscopy analysis confirmed the PS nature of the polymer for all beads and no

117 additional features were observed in the PS spectra across all particles. (Fig. S1). All tests (DLS

118 and exposures) were performed with the same batch of particles.

119 Dynamic Light Scattering (DLS) analysis

120 DLS (Zetasizer NanoZS; Malvern Instruments; United Kingdom) was used to determine the

121 aggregation state (polydispersity index - PDI; Arbitrary Units (A.U.)), the mean size of

122 particles/aggregates (hydrodynamic diameter; $\mathrm{nm}$ ) and the mean surface charge ( $\zeta$-potential; $\mathrm{mV}$ )

123 of MP/NP in two media: UW, as delivered by the supplier, and natural filtered seawater collected

124 from the Bay of Brest (FSW; 1- $\mu \mathrm{m}$ filtered and UV-treated; $\mathrm{pH} 8.1$ and 34 PSU). When PDI

125 exceeds 0.2, particles were considered to be aggregated. Measurements were performed in 
126 triplicate at $20^{\circ} \mathrm{C}$ (similar to the $\mathrm{T}^{\circ} \mathrm{C}$ used for bioassays) and a concentration of $100 \mu \mathrm{g} / \mathrm{mL}$ at $\mathrm{T} 0$

127 and T24h, each containing 13 runs (10 sec.measure $\left.{ }^{-1}\right)$ for PDI and hydrodynamic diameter, and

12840 runs (10 sec.measure ${ }^{-1}$ ) for $\zeta$-potential as conducted by González-Fernández et al. (2018). This 129 concentration was used for DLS analysis owing to the presence of artifacts at lower 130 concentrations.

\section{Suspensions of MP/NP for bioassays}

132 MP and NP stock suspensions were prepared in UW at $1,000 \mu \mathrm{g} / \mathrm{mL}$, while working suspensions 133 were prepared in FSW. Four concentrations of plastic were tested: 0.1, 1, 10 and $25 \mu \mathrm{g} / \mathrm{mL}$, plus

134 a control group $(0 \mu \mathrm{g} / \mathrm{mL})$, in order to identify toxicity thresholds. A total of 25 treatments (5 135 particle types $\times 5$ concentrations) were then tested on the three early stages (gametes, embryos 136 and larvae; see below).

\section{Biological material}

138 Oysters from 2 cohorts, produced in 2014 and 2015 according to Petton et al. (2015), were 139 deployed in 2016 in the bay of Brest and in the Marennes-Oléron basin (France). In the summer 140 of 2017, oysters were randomly sampled to collect their gametes for assays on gametes and 141 embryo-larval development. For the metamorphosis assay, pediveliger larvae (21 days old) were 142 purchased from a commercial hatchery (Société Atlantique de Mariculture, France).

\section{Gamete assay}

144 Sperm from two males and oocytes from three females were collected by stripping the gonad. 145 This was repeated in five replicates, involving a total of 10 males and 15 females. Sperm were 146 then sieved at $100 \mu \mathrm{m}$, and oocytes at $100 \mu \mathrm{m}$ then $20 \mu \mathrm{m}$ to eliminate debris (Steele and 147 Mulcahy, 1999). Oocytes were diluted in $2 \mathrm{~L}$ and sperm in $100 \mathrm{~mL}$ of FSW maintained at $21^{\circ} \mathrm{C} \pm$ 
$1481^{\circ} \mathrm{C}($ mean $\pm \mathrm{SD})$. Spermatozoa mobility and round shape of oocytes, used as proxies of gamete

149 quality, were checked by microscopy (Olympus BX51; $\times 10-20$ magnification with phase contrast

150 for sperm) (Fabbri et al., 2014). Spermatozoa and oocyte concentrations were estimated by flow

151 cytometry (EasyCyte Plus cytometer; Millipore Corporation; USA) (Le Goïc et al., 2014, 2013).

152 Gametes (1,000 oocytes/mL; 100:1 spermatozoa:oocyte ratio) were placed at the same time in 40

$153 \mathrm{~mL}$ glass vials filled with $30 \mathrm{~mL}$ of $\mathrm{FSW}$ at $21^{\circ} \mathrm{C} \pm 1{ }^{\circ} \mathrm{C}$, containing the MP or NP suspensions (5

154 particle types $\times 5$ concentrations; 5 replicates per treatment).

155 After $1.5 \mathrm{~h}$, samples were fixed with a formaldehyde-seawater solution $(0.1 \%$ final $)$ to estimate 156 the fertilization yield under a microscope (Zeiss Axio Observer Z1; $\times 10-40$ magnification;

157 observation of 150 oocytes per vial). The fertilization yield was defined as: (number of fertilized

158 oocytes / [number of fertilized and unfertilized oocytes]) $\times 100$ (Martínez-Gómez et al., 2017).

159 An oocyte was considered to be fertilized when polar bodies and cell divisions were observed.

160 Embryo-larval assay

161 The standardized AFNOR procedure (AFNOR XP-T-90-382) was used to perform this assay.

162 Fertilization was achieved in five replicates with gametes collected from five males and five

163 females per replicate (total: 25 males and 25 females) following the procedure described above.

164 Once fertilization was achieved in a 2-L glass beaker filled with $1.5 \mathrm{~L}$ of FSW with high

165 fertilization yields (>90\%; verified under a Zeiss Axio Observer Z1; $\times 10-40$ magnification),

1661,500 embryos were collected per replicate and diluted at a concentration of $60 \mathrm{embryos} / \mathrm{mL}$ in

$16740 \mathrm{~mL}$ glass vials filled with $25 \mathrm{~mL}$ of $\mathrm{FSW}\left(21^{\circ} \mathrm{C} \pm 1^{\circ} \mathrm{C}\right)$ containing the $\mathrm{MP}$ or NP suspensions

168 (5 particle types $\times 5$ concentrations; 5 replicates per treatment). After $36 \mathrm{~h}$ in dark conditions,

169 samples were fixed with a formaldehyde-seawater solution $(0.1 \%$ final $)$ to evaluate the D-larval 
170 yield under a microscope (Zeiss Axio Observer Z1; $\times 10-63$ magnification; observation of 100

171 larvae per vial). The D-larval yield was defined as: (number of normal D-larvae / number of

172 normal and abnormal D-larvae) $\times 100$ (Di Poi et al., 2014). A normal D-larvae indicated 173 embryogenic success, while an abnormal larva presented mantle, shell and/or hinge 174 malformations, or developmental arrest at the embryonic stage (Mottier et al., 2013).

\section{Metamorphosis assay}

176 The bioassay at the metamorphosis stage was performed as described in Di Poi et al. (2014).

177 Briefly, a total of $65 \pm 15$ pediveliger larvae per treatment were exposed to plastic particles in 12 178 well microplates (NUNC@ with the Nunclon ${ }^{\mathrm{TM}}$ Delta surface treatment) filled with $1.5 \mathrm{~mL}$ of 179 FSW containing the MP or NP suspensions (5 particle types $\times 5$ concentrations; 6 replicates per 180 treatment) for $24 \mathrm{~h}$ at $21^{\circ} \mathrm{C} \pm 1^{\circ} \mathrm{C}$. Metamorphosis of oyster larvae was stimulated by adding $10^{-4}$ 181 M epinephrine (Sigma-Aldrich; CAS number: 51-43-4) (Coon et al., 1990) immediately after the 182 start of the exposure (Di Poi et al., 2014). After the $24 \mathrm{~h}$ incubation, samples were fixed with a 183 formaldehyde-seawater solution $(0.1 \%$ final $)$ to determine the metamorphosis yield under a 184 microscope (Leica DM-IRB; $\times 10$ magnification; all larvae were observed). The metamorphosis 185 yield was defined as: (number of metamorphosed larvae / total number of larvae) $\times 100$. A 186 metamorphosed larva is characterized by a significant growth of shell and gills, and loss of the 187 velum and foot (Di Poi et al., 2014).

\section{Statistical analyses}

189 Statistical analyses and graphical representations were produced using the $\mathrm{R}$ software. 190 Percentages were analyzed after angular transformation. Normality and homogeneity of variance 191 were verified by the Shapiro-Wilk and Levene methods, respectively. The Student's $t$-test was 
192

193 particle concentrations on fertilization, embryo-larval development and metamorphosis success, parametric (ANOVA) or non-parametric (Kruskal-Wallis) analyses of variance were followed by post-hoc methods (Tukey or Conover) for pairwise comparisons when differences were detected. Whenever a dose-response pattern was observed, the package "DRC" was used to determine the half maximal effective concentration $\left(\mathrm{EC}_{50}\right)$, defined as the concentration of a substance leading to a significant effect in $50 \%$ of the population. All data are represented by means \pm standard 199 deviation (SD).

\section{Results}

\section{Particle characterization}

The $2-\mu \mathrm{m}$ and $500-\mathrm{nm}$ beads formed small aggregates in UW (PDI>0.2), whereas all NP remained in their original form $(\mathrm{PDI}<0.2$; Table 1$)$. For all particles, the aggregation state or size of aggregates increased significantly when added to seawater $(\mathrm{p}<0.01)$. Only the $\mathrm{NH}_{2}-50$ formed aggregates at the nanometer scale (mean \pm SD; $96.5 \pm 2.0 \mathrm{~nm})$ in FSW. The Plain-50 (5951.0 \pm $264.3 \mathrm{~nm})$ and $\mathrm{COOH}-50(3735.0 \pm 443.8 \mathrm{~nm})$ formed larger aggregates than the $2-\mu \mathrm{m}(3113.7 \pm$ $32.3 \mathrm{~nm})$ and $500-\mathrm{nm}(1620.7 \pm 188.8 \mathrm{~nm})$ beads in FSW. All particles presented a negative surface charge in UW and FSW, with the exception of $\mathrm{NH}_{2}-50$ that exhibited a positive surface

209 charge in all media. The seawater systematically buffered the charge of all MP/NP with mean 210 surface charge values decreasing towards zero in seawater compared to UW ( $<<0.01$; Table 1$)$.

211 No significant changes ( $\mathrm{p}>0.05)$ of charge and aggregation were observed between T0 and T24h 212 in FSW for all particles except the Plain-50 which formed bigger aggregates exceeding $10 \mu \mathrm{m}$ in 213 FSW (p<0.05; Table S1). 
215 The control treatment (0 plastic) presented a high fertilization yield (mean \pm SD; $92.3 \pm 1.0 \%$ ),

216 demonstrating the good quality/maturity of the gametes and the quality of the FSW. The 2- $\mu \mathrm{m}$

217 (Fig. 2A) and 500-nm (Fig. 2B) particles had no effect on the fertilization yield relative to the

218 control group ( $>00.05)$. All NP significantly impaired the fertilization yield in a dose-response

219 manner between 1 and $25 \mu \mathrm{g} / \mathrm{mL}$. Exposure to Plain-50 (Fig. 2C) led to significant reductions in

220 fertilization $(\mathrm{p}<0.05)$ of $2.7,55.7$ and $72.7 \%$ for 1,10 and $25 \mu \mathrm{g} / \mathrm{mL}$, respectively, associated

221 with an $\mathrm{EC}_{50}$ value of $12.3 \pm 7.5 \mu \mathrm{g} / \mathrm{mL}$. The COOH-50 particles (Fig. 2D) induced significant

222 decreases $(\mathrm{p}<0.05)$ of $3.8,65.7$ and $93.0 \%$ with an $\mathrm{EC}_{50}$ value of $7.8 \pm 1.1 \mu \mathrm{g} / \mathrm{mL}$. The $\mathrm{NH}_{2}-50$

223 exhibited the strongest toxicity inducing significant decreases $(p<0.05)$ in the fertilization yield of

$2246.3,75.4$ and $91.2 \%$ for increasing doses of NP associated with an $\mathrm{EC}_{50}$ value of $4.9 \pm 0.9 \mu \mathrm{g} / \mathrm{mL}$

225 (Fig. 2E; Fig. S2).

226 Embryo-larval assay

227 Exposure to 2- $\mu \mathrm{m}$ (Fig. 3A) and 500-nm (Fig. 3B) did not cause any significant effect on 228 embryo-larval development compared with the control treatment (mean $\pm \mathrm{SD} ; 93.3 \pm 1.5 \%$ ) at 36 229 hours post-fertilization (hfp). The D-larval yield was significantly reduced $(\mathrm{p}<0.01)$ by exposure 230 to 10 and $25 \mu \mathrm{g} / \mathrm{mL}$ of Plain-50 (Fig. 3C) leading to a mean reduction of 9.2 and $16.9 \%$, 231 respectively. This was insufficient to estimate a robust $\mathrm{EC}_{50}$ value for the Plain-50 (Fig. S3). 232 Exposure to $\mathrm{COOH}-50$ led to a mean reduction of 32.2 and $100 \%$ after exposure to 10 and 25 $233 \mu \mathrm{g} / \mathrm{mL}$, respectively (Fig. 3D) with an $\mathrm{EC}_{50}$ value of $11.60 \pm 10.5 \mu \mathrm{g} / \mathrm{mL}$. The highest toxicity 234 was observed for the $\mathrm{NH}_{2}-50$ with a significant decrease of $6.4 \%(\mathrm{p}<0.05)$ in the D-larval yield at 235 the lowest concentration $(0.1 \mu \mathrm{g} / \mathrm{mL})$, followed by a total inhibition (100\% reduction) of the 
236 embryo-larval development success for higher doses giving an $\mathrm{EC}_{50}$ value of $0.15 \pm 0.4 \mu \mathrm{g} / \mathrm{mL}$

237 (Fig. 3E; Fig. S3).

238 Compared to the control group where D-larvae appeared healthy (Fig. 4A), Plain-50 (10 and 25

$239 \mu \mathrm{g} / \mathrm{mL})$ and COOH-50 $(10 \mu \mathrm{g} / \mathrm{mL})$ caused numerous mantle or/and shell malformations (Fig.

240 4A-B). Only dead embryos/larvae were observed at the highest concentration of COOH-50 (Fig.

241 4D) whereas mainly cell debris were observed upon exposure to the three highest doses of $\mathrm{NH}_{2}-$

24250 (Fig. 4E-F). In both cases, this represents evidence of developmental arrest.

\section{Metamorphosis assay}

244 A high metamorphosis yield was observed in all treatments, ranging from $81.5 \pm 9.0$ to $90.8 \pm 2.4$

245 (mean $\pm \mathrm{SD}=86.6 \pm 3.6 \%)$, and no significant effect of $\mathrm{MP} / \mathrm{NP}$ exposure $(\mathrm{p}>0.05)$ on

246 metamorphosis success of $C$. gigas was demonstrated, regardless of particle type or 247 concentration. Furthermore, no abnormalities were observed under a microscope for any of the 248 treatments tested.

\section{Discussion}

250 Strong effects of NP were observed on the success of fertilization and embryogenesis of $C$. gigas 251 depending on particle dose and functionalization. Based on the commercial size, a higher toxicity 252 of NP compared to MP was demonstrated here, in agreement with previous observations across a 253 range of species, including copepods (Jeong et al., 2017, 2016; Lee et al., 2013), crustaceans (Ma 254 et al., 2016) and fish (Mattsson et al., 2017). This comparison was only done for plain particles, 255 and the functionalization-dependent toxicity remains to be tested for MP, especially using amine 256 groups displaying the strongest toxicity at the nanoscale. These insights support the purpose that 257 risks of NP may be higher than microscale counterparts (Wright and Kelly, 2017). Indeed, there 
258 is a consensus concerning the risk of nanomaterials as a result of their high reactivity and their

259 capacity to cross biological membranes (Nel et al., 2006). It is noteworthy that the short term 260 exposure to plain 500-nm and 2- $\mu \mathrm{m}$ beads did not show any effect on the two essential planktonic 261 stages of oyster reproduction and development (gametes and embryos), whereas deleterious 262 effects after 2-months of exposure to 2 and $6-\mu \mathrm{m}$ plain PS beads were previously demonstrated 263 on gametogenesis of adult oysters leading to subsequent negative impacts on unexposed gametes 264 and offspring (Sussarellu et al., 2016).

265 The dose-response exposure experiments performed here, which are the recommended approach 266 when environmental concentrations are unknown (e.g. Paul-Pont et al., 2018), allowed the 267 estimation of the half maximal effective concentration $\left(\mathrm{EC}_{50}\right)$ indicating the concentration of a 268 compound when $50 \%$ of its maximal effect is observed. The lowest $\mathrm{EC}_{50}$ was observed for the $269 \mathrm{NH}_{2}-50$, which was 1.6 to 77 times more toxic for gametes and embryos, respectively, than the $270 \mathrm{COOH}-50$. The highest $\mathrm{EC}_{50}$ in NP exposures was observed for the Plain-50 particles presumably 271 due to a decrease of their bioavailability owing to the presence of aggregates higher than $10 \mu \mathrm{m}$ 272 observed in seawater at T24h. Oyster embryos exhibited similar sensitivity as mussel embryos 273 (48h exposures; $\mathrm{EC}_{50} \mathrm{NH}_{2}-50: 0.14 \mu \mathrm{g} / \mathrm{mL}$ )(Balbi et al., 2017), but their sensitivity was higher 274 than that of sea urchin embryos (48h exposures; $\left.\mathrm{EC}_{50} \mathrm{NH}_{2}-50: 2.61 \mu \mathrm{g} / \mathrm{mL}\right)($ Della Torre et al., 275 2014), suggesting inter-species variability. Additionally, biological stage within the same species 276 appears to be an important factor in determining effects, considering the absence of NP toxicity 277 on metamorphosis success. As demonstrated here, oyster larvae seem to withstand MP/NP 278 exposures, in agreement with a previous study showing no effect on growth rate or survival of 279 oyster larvae upon exposure to 1 and $10 \mu \mathrm{m}$ PS particles for 8 days (Cole and Galloway, 2015). 280 The absence of toxicity of MP/NP on pediveliger oyster larvae is probably linked to a decrease in 
281 the larvae surface/volume ratio, and/or the appearance of a shell protecting larvae from

282 polystyrene particles (Hickman, 1999; Liebig and Vanderploeg, 1995; Schiaparelli et al., 2004).

283 The potential underlying mechanisms of NP toxicity include impairment of biological 284 membranes, sub-cellular toxicity or physical blockages, notably for spermatozoa. These 285 explanatory hypotheses, discussed below, are not mutually exclusive and could all play a role in the observed adverse effects of $\mathrm{NH}_{2}-50$, Plain-50 and $\mathrm{COOH}-50$ on oyster planktonic stages.

287 The observed toxicity of nano-PS on gametes and embryos may be related to damage caused by membrane breakages (Nel et al., 2009). Indeed, adhesion of nanoplastics on oyster gametes, both oocytes and spermatozoa (González-Fernández et al., 2018), and sea urchin and mussel embryos

290 (Della Torre et al., 2014; Balbi et al., 2017) was recently demonstrated. We can rely on these 291 published data from different models and particles to suggest that NP have stuck on oyster's 292 gametes and embryos. Consequences might be significant for biological membranes: molecular 293 simulations have demonstrated the capacity of nano-PS to perturb lipid membranes (Rossi et al., 294 2014). Even if metallic and plastic nanoparticles cannot be directly compared, nickel and iron 295 nanoparticles reduced the membrane integrity of Ciona instinalis (Gallo et al., 2016) and Mytilus 296 edulis spermatozoa, leading to a decrease in fertilization success (Kadar et al., 2011). Interactions 297 between nanoparticles and biological membranes are driven by particle aggregation and size. 298 Here, the most toxic nanoplastics $\left(\mathrm{NH}_{2}-50\right)$ remained at the nanometer size in seawater and were 299 thus expected to interact more with biological membranes through their higher reactivity and 300 capacity to cross biological membranes (Nel, 2006; Verma and Stellacci, 2010). Similarly, 301 exposure to $\mathrm{NH}_{2}-50$ led to higher toxicity in sea urchin embryos and shrimp larvae (Bergami et 302 al., 2016; Della Torre et al., 2014), compared to COOH-40 nm forming approximatively $1 \mu \mathrm{m}$ 303 aggregates in seawater. The major differences in aggregation observed for the different 
nanobeads in ultrapure water and filtered seawater are a result of the characteristics of the

305 nanobeads themselves and the surrounding medium (Nel et al., 2009; Rocha et al., 2015). The high aggregation of $\mathrm{COOH}-50$ and Plain-50 observed here in filtered seawater can be explained by a strong interaction between the negative surface charge of these NP and the abundant cationic

308 ions such as $\mathrm{Ca}^{2+}$ in seawater. It is noteworthy that Plain-50 forming micrometric sized 309 aggregates led to significant toxicity on gametes and embryos while plain MP exhibiting lower 310 micrometric size $(2 \mu \mathrm{m})$ seemed innocuous. This suggests that nanoparticles remain highly 311 reactive with biological membrane even in the form of large aggregates.

312 The differential interactions between cells and nanoparticles may also be linked to their surface 313 properties, notably the net surface charge (Nel et al., 2009). The so-called buffering effect 314 observed on the net surface charge of MP/NP incubated in filtered seawater compared to 315 ultrapure water is also related to the presence of anions and cations in seawater that would have 316 interacted with their surface layer. The ions brought the $\zeta$-Potential to a neutral surface charge, 317 and as a result, decreased NP stability (El Badawy et al., 2010; Lin et al., 2010). The lowest 318 surface charge observed for the Plain-50 may lead to reduced interaction with gamete and 319 embryo membranes, explaining their lower toxicity compared to other NP. Cationic nanoparticles 320 interact with negative membrane residuals more easily than anionic ones, and this interaction 321 triggers internalization to maintain the overall negative membrane charge, which may eventually 322 induce membrane disruptions (Cho et al., 2009; Fröhlich, 2012). Furthermore, a chemical effect 323 of the functionalization cannot be excluded and will be dependent on the commercial products 324 and their manufacturers.

325 Impairment of membrane integrity during cell divisions can lead to developmental arrest during 326 embryogenesis (Rossi et al., 2014), in agreement with the numerous malformations we observed 
upon NP exposure. These results call for detailed microscopic analyses of exposed cell

328 membranes, coupled with lipidomic approaches to assess lipid membrane composition upon NP

329 exposure, in order to better understand the effects of NP on membrane integrity.

330 Given the high aggregation $(3-10 \mu \mathrm{m})$ observed in our data for the Plain-50 and COOH-50, 331 congestion of gametes is a possibility; our previous study demonstrated the adhesion of 332 carboxylic nanopolystyrene $(100 \mathrm{~nm})$ on oyster spermatozoa (González-Fernández et al., 2018).

333 This congestion may hamper spermatozoa internalization into oocytes, leading to negative effects 334 on the fertilization yield as observed upon exposure to Plain-50 and COOH-50.

335 Among the numerous physicochemical properties of the particles, including size, surface charge, 336 aspect ratio, porosity that impact in vivo behavior of MP and NP, surface corona is of real 337 importance (e.g. Galloway et al., 2017). Indeed, corona formation on nano-PS can fluctuate 338 depending on the surface properties of the particle, i.e. functionalization and charge (Lundqvist et 339 al., 2008). It can affect the particle chemical identity with significant consequences on ingestion 340 and interaction with cells and organs (Hristov et al., 2015; Canesi et al., 2016; Nasser \& Lynch, 341 2016). Further studies are required to characterize the NP-cell interactions (entry, adhesion and 342 membrane impairments) in oyster gametes and embryos and to understand the toxic pathways 343 involved.

344 At the same time, the NP toxicity observed here could be related to sub-cellular toxicity upon 345 internalization and/or membrane disruption of gametes/embryos. For instance, $\mathrm{NH}_{2}-50$ was better 346 internalized in human cell lines representing various organs, and led to more cytotoxic effects 347 than COOH-50 and Plain-50 (Anguissola et al., 2014; Bannunah et al., 2014). Similar 348 mechanisms, involving NP entry leading to sub-cellular toxicity, could also be hypothesized here 349 requiring fine microscopical observations using fluorescent NP. In the present study, the 
350

351

352

353

354 367 (100 nm) (González-Fernández et al., 2018).

368 The lowest concentration $(0.1 \mu \mathrm{g} / \mathrm{mL})$ used here was five times higher than the mass 369 concentration of MP used in the study of Sussarellu et al. (2016) based on equivalent mass 370 concentration of $>333 \mu \mathrm{m}$ plastics debris hotspots. At this concentration, only exposure of oyster 371 embryos to $\mathrm{NH}_{2}-50$ had a significant effect, which suggests that the probability of oyster 372 planktonic stages suffering fertilization and embryo-larval development disruptions due to NP

exclusive occurrence of developmental arrest during exposure at the highest concentrations of $\mathrm{NH}_{2}-50$ and $\mathrm{COOH}-50$ could indicate the involvement of apoptosis pathways, as described in the sea urchin Paracentrotus lividus (Della Torre et al., 2014; Pinsino et al., 2017). The intermediate situation, where malformed larvae (mantle, shell and hinge malformations) were observed upon exposure to Plain-50, intermediate concentrations of $\mathrm{COOH}-50$ and the lowest concentration of $\mathrm{NH}_{2}-50$, could be a result of dysregulation of genes involved in shell mineralization, as previously demonstrated by transcriptional analysis in mussel embryos exposed to $0.15 \mu \mathrm{g} / \mathrm{mL}$ of $\mathrm{NH}_{2}-50$. Another toxic effect, previously characterized during exposure to chemical agents and nanoplastics, involves a decrease in DNA integrity or a disruption of the cell oxidative balance of oyster gametes and embryos (Akcha et al., 2012; Behrens et al., 2016; Vignier et al., 2017; González-Fernández et al., 2018). Nanoparticles can interfere with electron transfer of the intracellular medium, inducing a production of ROS (superoxide anion / hydroxyl radical, hydrogen peroxide) and generating disruption of redox functions (Fu et al., 2014). This overproduction of ROS results in several types of damage, such as lipid peroxidation or DNA breakages leading to embryotoxicity (Xie et al., 2017). In agreement with these observations we previously suggested that spermatozoa may lose their ability to fertilize oocytes as a consequence of an oxidative stress induced by exposure of oyster spermatozoa to carboxylic nanopolystyrene plaktonic stages suffering fertilization and embryo-larval development disruptions due to NP 
373 exposure is low in nature at the present time. However, taking into account the calculations of

374 Besseling et al. (2014), the toxic effects observed here began at lower concentrations than the 375 highest mass concentration of plastic debris $(16.9 \mu \mathrm{g} / \mathrm{mL})$ estimated at the water-sediment 376 interface. This location is known for its high plastic contamination and where wild adult oysters 377 live and spawn (Martin et al., 2017). Furthermore, the power-law increase in MP concentration 378 with decreasing particle size in sea surface samples suggests that small MP are increasingly 379 abundant, and that MP concentrations will be underestimated if the smallest fraction is not 380 properly quantified (Bergmann et al., 2017; Erni-Cassola et al., 2017).

381 With regards to the increase of (nano)plastics used in industry (GESAMP 2015), the recent 382 estimation of their mismanagement and release into oceans worldwide, as well as the continuous 383 breakdown of plastic waste at the nanometer scale, better management of end-of-life plastics is 384 should be strongly recommend to enable a transition to a circular economy (Brink et al. 2017) 385 and limit or prevent accidental releases. For instance, nano- $\mathrm{TiO}_{2}$ levels are expected to reach up 386 to $1 \mu \mathrm{g} / \mathrm{mL}$ in nature (Holden et al., 2014), although its estimated accidental release in the marine 387 environment is much lower (between 2 and 6 million tons over the next 10 years (Haynes et al., 388 2017)) than that estimated for plastic wastes. The latter were estimated between 4.8 and 12.7 389 million tons in 2010 alone, with an expected increase of an order of magnitude by 2025 (Jambeck 390 et al., 2015).

\section{Conclusion}

392 Our study is the first demonstration of adverse effects of nanoplastics on oyster early-life stages, 393 with the fertilization/embryogenesis steps being particularly sensitive. The combination of fine 394 microscopy and Omics (lipidomics, transcriptomics) tools is now needed to fully understand the 395 underlying toxicity mechanisms that likely include both membrane disruption and sub-cellular 
toxicity. Significant ecological implications can be expected as effects on gametes, fertilization

397 and embryo-larval development determine recruitment, population stability and ecosystem 398 structure. Indeed, oysters sustain the formation of reefs providing micro-habitats for a large 399 community of invertebrates and nursery areas for pelagic organisms (Bayne, 2017). We suggest 400 that direct effects on early-life stages should be integrated into the "adverse outcome pathway" 401 (AOP) scheme describing microplastic toxicity pathways in aquatic organisms (Galloway and 402 Lewis, 2016). Indeed, this additional pathway may influence the offspring viability and the 403 overall reproductive output. In this context, our work highlights the interest of using oysters as a 404 model to describe the risk of plastic debris in coastal and estuarine areas where a high spatial 405 variability of contamination is expected.

\section{Acknowledgment}

407 This study was financially supported by the ANR-Nanoplastics project (ANR-15-CE34-0006). K. 408 Tallec was funded by a French doctoral research grant from the region Bretagne (50\%) and 409 Ifremer (50\%). The authors thank E. Fleury, M. Boulais, V. Foulon, J. Castrec, M. Suquet, A-L 410 Cassone and the staff of the experimental station of Argenton, JL. Seugnet and the RESCO team 411 for their help with the experimental work, PA. Jaffres and O. Lozach (UMR-CNRS 6521) for 412 their support and expertise with the DLS, and H. McCombie for her help in editing the English.

\section{References}

414 Akcha, F., Spagnol, C., Rouxel, J., 2012. Genotoxicity of diuron and glyphosate in oyster 415 spermatozoa and embryos. Aquat. Toxicol. 106-107, 104-113. $416 \quad$ https://doi.org/10.1016/j.aquatox.2011.10.018

417 Anguissola, S., Garry, D., Salvati, A., O’Brien, P.J., Dawson, K.A., 2014. High content analysis 418 provides mechanistic insights on the pathways of toxicity induced by amine-modified 419 polystyrene nanoparticles. PLoS One 9. https://doi.org/10.1371/journal.pone.0108025 
Avio, C.G., Gorbi, S., Milan, M., Benedetti, M., Fattorini, D., D’Errico, G., Pauletto, M., Bargelloni, L., Regoli, F., 2015. Pollutants bioavailability and toxicological risk from microplastics to marine mussels. Environ. Pollut. 198, 211-222. https://doi.org/10.1016/j.envpol.2014.12.021

Balbi, T., Camisassi, G., Montagna, M., Fabbri, R., Franzellitti, S., Carbone, C., Dawson, K., Canesi, L., 2017. Impact of cationic polystyrene nanoparticles (PS-NH$)$ on early embryo development of Mytilus galloprovincialis: Effects on shell formation. Chemosphere 186, 19. https://doi.org/10.1016/j.chemosphere.2017.07.120

Bannunah, A.M., Vllasaliu, D., Lord, J., Stolnik, S., 2014. Mechanisms of Nanoparticle Internalization and Transport Across an Intestinal Epithelial Cell Model: Effect of Size and Surface Charge. Mol. Pharm. 11, 4363-4373. https://doi.org/10.1021/mp500439c

Bayne, B., 2017. Biology of oyster $1^{\text {st }}$ Edition. Eds Academic Press, 862 pp.

Bayne, B.L., Ahrens, M., Allen, S.K., D’auriac, M.A., Backeljau, T., Beninger, P., Bohn, R., Boudry, P., Davis, J., Green, T., Guo, X., Hedgecock, D., Ibarra, A., Kingsley-Smith, P., Krause, M., Langdon, C., Lapègue, S., Li, C., Manahan, D., Mann, R., Perez-Paralle, L., Powell, E.N., Rawson, P.D., Speiser, D., Sanchez, J.-L., Shumway, S., Wang, H., 2017. The Proposed Dropping of the Genus Crassostrea for All Pacific Cupped Oysters and Its Replacement by a New Genus Magallana: A Dissenting View. J. Shellfish Res. 36, 545547. https://doi.org/10.2983/035.036.0301

Behrens, D., Rouxel, J., Burgeot, T., Akcha, F., 2016. Comparative embryotoxicity and genotoxicity of the herbicide diuron and its metabolites in early life stages of Crassostrea gigas: Implication of reactive oxygen species production. Aquat. Toxicol. 175, 249-259. https://doi.org/10.1016/j.aquatox.2016.04.003

Bergami, E., Bocci, E., Luisa, M., Monopoli, M., Salvati, A., Dawson, K.A., Corsi, I., 2016. Nano-sized polystyrene affects feeding, behavior and physiology of brine shrimp Artemia franciscana larvae. Ecotoxicol. Environ. Saf. 123, 18-25. https://doi.org/10.1016/j.ecoenv.2015.09.021

Bergmann, M., Wirzberger, V., Krumpen, T., Lorenz, C., Primpke, S., Tekman, M.B., Gerdts, G., 2017. High quantities of microplastic in Arctic deep-sea sediments from the HAUSGARTEN observatory. Environ. Sci. Technol. acs.est.7b03331. https://doi.org/10.1021/acs.est.7b03331

Besseling, E., Wang, B., Lürling, M., Koelmans, A.A., 2014. Nanoplastic affects growth of S. obliquus and reproduction of D. magna. Environ. Sci. Technol. 48, 12336-12343. https://doi.org/10.1021/es503001d 
Canesi, L., Ciacci, C., Fabbri, R., Balbi, T., Salis, A., Damonte, G., Cortese, K., Caratto, V., Monopoli, M.P., Dawson, K., Bergami, E., Corsi, I., 2016. Interactions of cationic polystyrene nanoparticles with marine bivalve hemocytes in a physiological environment: Role of soluble hemolymph proteins. Environ. Res. 150, 73-81. https://doi.org/10.1016/j.envres.2016.05.045

Cho, E.C., Xie, J., Wurm, P.A., Xia, Y., 2009. Understanding the role of surface charges in cellular adsorption versus internalization by selectively removing gold nanoparticles on the cell surface with a I 2/KI etchant. Nano Lett. 9, 1080-1084. https://doi.org/10.1021/n1803487r

Cole, M., Galloway, T.S., 2015. Ingestion of Nanoplastics and Microplastics by Pacific Oyster Larvae. Environ. Sci. Technol. 49, 14625-14632. https://doi.org/10.1021/acs.est.5b04099

Cole, M., Lindeque, P., Fileman, E., Halsband, C., Goodhead, R., Moger, J., Galloway, T.S., 2013. Microplastic ingestion by zooplankton. Environ. Sci. Technol. 47, 6646-6655. https://doi.org/10.1021/es400663f

Cole, M., Lindeque, P., Halsband, C., Galloway, T.S., 2011. Microplastics as contaminants in the marine environment: A review. Mar. Pollut. Bull. 62, 2588-2597. https://doi.org/10.1016/j.marpolbul.2011.09.025

Coon, S.L., Walch, M., Fitt, W.K., Weiner, R.M., Bonar, D.B., 1990. Ammonia Induces Settlement Behavior in Oyster Larvae. Biol. Bull. 179, 297-303. https://doi.org/10.2307/1542321

Cózar, A., Martí, E., Duarte, C.M., García-de-Lomas, J., van Sebille, E., Ballatore, T.J., Eguíluz, V.M., González-Gordillo, J.I., Pedrotti, M.L., Echevarría, F., Troublè, R., Irigoien, X., 2017. The Arctic Ocean as a dead end for floating plastics in the North Atlantic branch of the Thermohaline Circulation. Sci. Adv. 3, e1600582. https://doi.org/10.1126/sciadv.1600582

Cui, R., Kim, S.W., An, Y.-J., 2017. Polystyrene nanoplastics inhibit reproduction and induce abnormal embryonic development in the freshwater crustacean Daphnia galeata. Sci. Rep. 7, 12095. https://doi.org/10.1038/s41598-017-12299-2

da Costa, J.P., Santos, P.S.M., Duarte, A.C., Rocha-Santos, T., 2016. (Nano)plastics in the environment - Sources, fates and effects. Sci. Total Environ. 566-567, 15-26. https://doi.org/10.1016/j.scitotenv.2016.05.041

Dawson, A.L., Kawaguchi, S., King, C.K., Townsend, K.A., King, R., Huston, W.M., Bengtson Nash, S.M., 2018. Turning microplastics into nanoplastics through digestive fragmentation by Antarctic krill. Nat. Commun. 9, 1001. https://doi.org/10.1038/s41467-018-03465-9 
Della Torre, C., Bergami, E., Salvati, A., Faleri, C., Cirino, P., Dawson, K.A., Corsi, I., 2014. Accumulation and Embryotoxicity of Polystyrene Nanoparticles at Early Stage of Development of Sea Urchin Embryos Paracentrotus lividus. Environ. Sci. Technol. 48, 12302-12311. https://doi.org/10.1021/es502569w

Di Poi, C., Evariste, L., Serpentini, A., Halm-Lemeille, M.P., Lebel, J.M., Costil, K., 2014. Toxicity of five antidepressant drugs on embryo-larval development and metamorphosis success in the Pacific oyster, Crassostrea gigas. Environ. Sci. Pollut. Res. 21, 13302-13314. https://doi.org/10.1007/s11356-013-2211-y

Dubey, M.K., Bijwe, J., Ramakumar, S.S. V, 2015. Nano-PTFE: New entrant as a very promising EP additive. Tribol. Int. 87, 121-131. https://doi.org/10.1016/j.triboint.2015.01.026

El Badawy, A.M., Luxton, T.P., Silva, R.G., Scheckel, K.G., Suidan, M.T., Tolaymat, T.M., 2010. Impact of Environmental Conditions (pH, Ionic Strength, and Electrolyte Type) on the Surface Charge and Aggregation of Silver Nanoparticles Suspensions. Environ. Sci. Technol. 44, 1260-1266. https://doi.org/10.1021/es902240k

Eriksen, M., Lebreton, L.C.M., Carson, H.S., Thiel, M., Moore, C.J., Borerro, J.C., Galgani, F., Ryan, P.G., Reisser, J., 2014. Plastic Pollution in the World's Oceans: More than 5 Trillion Plastic Pieces Weighing over 250,000 Tons Afloat at Sea. PLoS One 9, 1-15. https://doi.org/10.1371/journal.pone.0111913

Erni-Cassola, G., Gibson, M.I., Thompson, R.C., Christie-Oleza, J.A., 2017. Lost, but Found with Nile Red: A Novel Method for Detecting and Quantifying Small Microplastics (1 mm to $20 \mu \mathrm{m})$ in Environmental Samples. Environ. Sci. Technol. 51, 13641-13648. https://doi.org/10.1021/acs.est.7b04512

Fabbri, R., Montagna, M., Balbi, T., Raffo, E., Palumbo, F., Canesi, L., 2014. Adaptation of the bivalve embryotoxicity assay for the high throughput screening of emerging contaminants in Mytilus galloprovincialis. Mar. Environ. Res. 99, 1-8. https://doi.org/10.1016/j.marenvres.2014.05.007

Fröhlich, E., 2012. The role of surface charge in cellular uptake and cytotoxicity of medical nanoparticles. Int. J. Nanomedicine 7, 5577. https://doi.org/10.2147/IJN.S36111

Fu, P.P., Xia, Q., Hwang, H.-M., Ray, P.C., Yu, H., 2014. Mechanisms of nanotoxicity: generation of reactive oxygen species. J. food drug Anal. 22, 64-75. https://doi.org/10.1016/j.jfda.2014.01.005

Gallo, A., Boni, R., Buttino, I., Tosti, E., 2016. Spermiotoxicity of nickel nanoparticles in the marine invertebrate Ciona intestinalis (ascidians). Nanotoxicology 10, 1096-1104. https://doi.org/10.1080/17435390.2016.1177743 
Galloway, T.S., Cole, M., Lewis, C., Atkinson, A., Allen, J.I., 2017. Interactions of microplastic debris throughout the marine ecosystem. Nat. Ecol. Evol. 1, 116. https://doi.org/10.1038/s41559-017-0116

Galloway, T.S., Lewis, C.N., 2016. Marine microplastics spell big problems for future generations. Proc. Natl. Acad. Sci. USA 113, 2331-2333. https://doi.org/10.1073/pnas.1600715113

Gardon, T., Reisser, C., Soyez, C., Quillien, V., \& Le Moullac, G., 2018. Microplastics Affect Energy Balance and Gametogenesis in the Pearl Oyster Pinctada margaritifera. Environmental Science \& technology, 52(9), 5277-5286.

GESAMP (2015). "Sources, fate and effects of microplastics in the marine environment: a global
assessment"
(Kershaw,
P. J.,
ed.).
(IMO/FAO/UNESCO-

IOC/UNIDO/WMO/IAEA/UN/UNEP/UNDP Joint Group of Experts on the Scientific Aspects of Marine Environmental Protection). Rep. Stud. GESAMP No. 90, 96.

Geyer, R., Jambeck, J.R., Law, K.L., 2017. Production, use, and fate of all plastics ever made. Sci. Adv. 3, e1700782. https://doi.org/10.1126/sciadv.1700782

Gigault, J., Ter Halle, A., Baudrimont, M., Pascal, P., Gauffre, F., Phi, T.-L., El Hadri, H., Grassl, B., Reynaud, S., 2018. Current opinion: What is a nanoplastic? Environ. Pollut. 235, 10301034. https://doi.org/10.1016/j.envpol.2018.01.024

Gigault, J., Pedrono, B., Maxit, B., Ter Halle, A., 2016. Marine plastic litter: the unanalyzed nano-fraction. Environ. Sci. Nano 3, 346-350. https://doi.org/10.1039/C6EN00008H

González-Fernández, C., Tallec, K., Le Goïc, N., Lambert, C., Soudant, P., Huvet, A., Suquet, M., Berchel, M., Paul-Pont, I., 2018. Cellular responses of Pacific oyster (Crassostrea gigas) gametes exposed in vitro to polystyrene nanoparticles. Chemosphere 208, 764-772. https://doi.org/10.1016/j.chemosphere.2018.06.039

Green, D.S., Boots, B., O'Connor, N.E., Thompson, R., 2016. Microplastics affect the ecological functioning of an important biogenic habitat. Environ. Sci. Technol. 51, 68-77. https://doi.org/10.1021/acs.est.6b04496

Haynes, V.N., Ward, J.E., Russell, B.J., Agrios, A.G., 2017. Photocatalytic effects of titanium dioxide nanoparticles on aquatic organisms-Current knowledge and suggestions for future research. Aquat. Toxicol. 185, 138-148. https://doi.org/10.1016/j.aquatox.2017.02.012

Hernandez, L.M., Yousefi, N., Tufenkji, N., 2017. Are There Nanoplastics in Your Personal Care Products? Environ. Sci. Technol. Lett. 4, 280-285. https://doi.org/10.1021/acs.estlett.7b00187 
Hickman, C.S., 1999. Adaptive Function of Gastropod Larval Shell Features. Invertebr. Biol. 118, 346-356. https://doi.org/ 10.2307/3227006

Holden, P.A., Klaessig, F., Turco, R.F., Priester, J.H., Rico, C.M., Avila-Arias, H., Mortimer, M., Pacpaco, K., Gardea-Torresdey, J.L., 2014. Evaluation of Exposure Concentrations Used in Assessing Manufactured Nanomaterial Environmental Hazards: Are They Relevant? Environ. Sci. Technol. 48, 10541-10551. https://doi.org/10.1021/es502440s

Hristov, D.R., Rocks, L., Kelly, P.M., Thomas, S.S., Pitek, A.S., Verderio, P., Mahon, E., Dawson, K.A., (2015). Tuning of nanoparticle biological functionality through controlled surface chemistry and characterisation at the bioconjugated nanoparticle surface. Sci. Rep, 5, 17040. https://doi.org/10.1038/srep17040.

Huvet, A., Paul-Pont, I., Fabioux, C., Lambert, C., Suquet, M., Thomas, Y., Robbens, J., Soudant, P., Sussarellu, R., 2016. Reply to Lenz et al.: Quantifying the smallest microplastics is the challenge for a comprehensive view of their environmental impacts. Proc. Natl. Acad. Sci. USA 113, E4123-E4124. https://doi.org/10.1073/pnas.1607221113

Jambeck, J.R., Geyer, R., Wilcox, C., Siegler, T.R., Perryman, M., Andrady, A., Narayan, R., Law, K.L., 2015. Plastic waste inputs from land into the ocean. Science 347, 768-771. https://doi.org/10.1126/science.1260352

Jeong, C.B., Kang, H.M., Lee, M.C., Kim, D.H., Han, J., Hwang, D.S., Souissi, S., Lee, S.J., Shin, K.H., Park, H.G., Lee, J.S., 2017. Adverse effects of microplastics and oxidative stress-induced MAPK/Nrf2 pathway-mediated defense mechanisms in the marine copepod Paracyclopina nana. Sci. Rep. 7, 1-11. https://doi.org/10.1038/srep41323

Jeong, C.B., Won, E.J., Kang, H.M., Lee, M.C., Hwang, D.S., Hwang, U.K., Zhou, B., Souissi, S., Lee, S.J., Lee, J.S., 2016. Microplastic Size-Dependent Toxicity, Oxidative Stress Induction, and p-JNK and p-p38 Activation in the Monogonont Rotifer (Brachionus koreanus). Environ. Sci. Technol. 50, 8849-8857. https://doi.org/10.1021/acs.est.6b01441

Kadar, E., Tarran, G.A., Jha, A.N., Al-Subiai, S.N., 2011. Stabilization of engineered zero-valent nanoiron with Na-acrylic copolymer enhances spermiotoxicity. Environ. Sci. Technol. 45, 3245-3251. https://doi.org/10.1021/es1029848

Klaine, S.J., Koelmans, A.A., Horne, N., Carley, S., Handy, R.D., Kapustka, L., Nowack, B., von der Kammer, F., 2012. Paradigms to assess the environmental impact of manufactured nanomaterials. Environ. Toxicol. Chem. 31, 3-14. https://doi.org/10.1002/etc.733

Lambert, S., Wagner, M., 2016. Characterisation of nanoplastics during the degradation of polystyrene. Chemosphere 145, $265-268$. https://doi.org/10.1016/j.chemosphere.2015.11.078 
588

589

590

591

592

593

594

595

596

597

598

599

600

601

602

603

604

605

606

607

608

609

610

611

612

613

614

615

616

617

618

619

620

Lavers, J.L., Bond, A.L., 2017. Exceptional and rapid accumulation of anthropogenic debris on one of the world's most remote and pristine islands. Proc. Natl. Acad. Sci. USA 114, 60526055. https://doi.org/10.1073/pnas.1619818114

Le Goïc, N., Hégaret, H., Boulais, M., Béguel, J.-P., Lambert, C., Fabioux, C., Soudant, P., 2014. Flow cytometric assessment of morphology, viability, and production of reactive oxygen species of Crassostrea gigas oocytes. Application to Toxic dinoflagellate (Alexandrium minutum) exposure. Cytom. Part A 85, 1049-1056. https://doi.org/10.1002/cyto.a.22577

Le Goïc, N., Hégaret, H., Fabioux, C., Miner, P., Suquet, M., Lambert, C., Soudant, P., 2013. Impact of the toxic dinoflagellate Alexandrium catenella on Pacific oyster reproductive output: application of flow cytometry assays on spermatozoa. Aquat. Living Resour. 26, 221-228. https://doi.org/10.1051/alr/2013047

Lee, K., Shim, W.J., Kwon, O.Y., Kang, J., 2013. Size-Dependent Effects of Micro Polystyrene Particles in the Marine Copepod Tigriopus japonicus. Environ. Sci. Technol. 47, 1127811283. https://doi.org/dx.doi.org/10.1021/es401932b

Liebig, J.R., Vanderploeg, H.A., 1995. Vulnerability of Dreissena polymorpha Larvae to Predation by Great Lakes Calanoid Copepods: the Importance of the Bivalve Shell. J. Great Lakes Res. 21, 353-358. https://doi.org/10.1016/S0380-1330(95)71046-2

Lin, D., Tian, X., Wu, F., Xing, B., 2010. Fate and Transport of Engineered Nanomaterials in the Environment. J. Environ. Qual. 39, 1896. https://doi.org/10.2134/jeq2009.0423

Lundqvist, M., Stigler, J., Elia, G., Lynch, I., Cedervall, T., Dawson, K.A, 2008. Nanoparticle size and surface properties determine the protein corona with possible implications for biological impacts. Proc. Natl. Acad. Sci. USA 105, 14265-14270. https://doi.org/10.1073/pnas.0805135105

Lusher, A. L., Hollman, P. C. H., Mendoza-Hill, J. J., 2017. Microplastics in Fisheries and Aquaculture: Status of Knowledge on their Occurrence and Implications for Aquatic Organisms and Food Safety. FAO Fisheries and Aquaculture Technical Paper. No. 615, 147 pp.

Ma, Y., Huang, A., Cao, S., Sun, F., Wang, L., Guo, H., Ji, R., 2016. Effects of nanoplastics and microplastics on toxicity, bioaccumulation, and environmental fate of phenanthrene in fresh water. Environ. Pollut. 219, 166-173. https://doi.org/10.1016/j.envpol.2016.10.061

Martin, J., Lusher, A., Thompson, R.C., Morley, A., 2017. The Deposition and Accumulation of Microplastics in Marine Sediments and Bottom Water from the Irish Continental Shelf. Sci. Rep. 1-9. https://doi.org/10.1038/s41598-017-11079-2 
Martínez-Gómez, C., León, V.M., Calles, S., Gomáriz-Olcina, M., Vethaak, A.D., 2017. The adverse effects of virgin microplastics on the fertilization and larval development of sea urchins. Mar. Environ. Res. 130, 69-76. https://doi.org/10.1016/j.marenvres.2017.06.016

Mattsson, K., Hansson, L.-A., Cedervall, T., 2015a. Nano-plastics in the aquatic environment. Environ. Sci. Process. Impacts 17, 1712-1721. https://doi.org/10.1039/C5EM00227C

Mattsson, K., Ekvall, M.T., Hansson, L.A., Linse, S., Malmendal, A., Cedervall, T., $2015 b$. Altered behavior, physiology, and metabolism in fish exposed to polystyrene nanoparticles. Environ. Sci. Technol. 49, 553-561. https://doi.org/10.1021/es5053655

Mattsson, K., Johnson, E. V., Malmendal, A., Linse, S., Hansson, L.-A., Cedervall, T., 2017. Brain damage and behavioural disorders in fish induced by plastic nanoparticles delivered through the food chain. Sci. Rep. 7, 11452. https://doi.org/10.1038/s41598-017-10813-0

Mottier, A., Kientz-Bouchart, V., Serpentini, A., Lebel, J.M., Jha, A.N., Costil, K., 2013. Effects of glyphosate-based herbicides on embryo-larval development and metamorphosis in the Pacific oyster, Crassostrea gigas. Aquat. Toxicol. 128-129, 67-78. https://doi.org/10.1016/j.aquatox.2012.12.002

Nasser, F., Lynch, I., 2016. Secreted protein eco-corona mediates uptake and impacts of polystyrene nanoparticles on Daphnia magna. J. Proteomics 137, 45-51. https://doi.org/10.1016/j.jprot.2015.09.005

Nel, A., Xia, T., Mädler, L., Li, N., 2006. Toxic Potential of Materials at the Nanolevel. Science. 311, 622-627. https://doi.org/10.1126/science.1114397

Nel, A.E., Mädler, L., Velegol, D., Xia, T., Hoek, E.M. V, Somasundaran, P., Klaessig, F., Castranova, V., Thompson, M., 2009. Understanding biophysicochemical interactions at the nano-bio interface. Nat. Mater. 8, 543-557. https://doi.org/10.1038/nmat2442

Ogonowski, M., Schür, C., Jarsén, Å., Gorokhova, E., 2016. The Effects of Natural and Anthropogenic Microparticles on Individual Fitness in Daphnia magna. PLoS One 11, e0155063. https://doi.org/10.1371/journal.pone.0155063

Ostroumov, S.A., 2003. Studying effects of some surfactants and detergents on filter-feeding bivalves. Hydrobiologia 500, 341-344. https://doi.org/10.1023/A:1024604904065

Paul-Pont, I., Tallec, K., González Fernández, C., Lambert, C., Vincent, D., Mazurais, D., Zambonino-Infante, J-L., Brotons, G., Lagarde, F., Fabioux, F., Soudant, P., Huvet, A., 2018. Constraints and Priorities for Conducting Experimental Exposures of Marine Organisms to Microplastics. Front. Mar. Sci. 5, 252. https://doi.org/10.3389/fmars.2018.00252 
Paul-Pont, I., Lacroix, C., González Fernández, C., Hégaret, H., Lambert, C., Le Goïc, N., Frère, L., Cassone, A.-L., Sussarellu, R., Fabioux, C., Guyomarch, J., Albentosa, M., Huvet, A., Soudant, P., 2016. Exposure of marine mussels Mytilus spp. to polystyrene microplastics: Toxicity and influence on fluoranthene bioaccumulation. Environ. Pollut. 216, 724-737. https://doi.org/10.1016/j.envpol.2016.06.039

Petton, B., Boudry, P., Alunno-Bruscia, M., Pernet, F., 2015. Factors influencing disease-induced mortality of Pacific oysters Crassostrea gigas. Aquac. Environ. Interact. 6, 205-222. https://doi.org/10.3354/aei00125

Pinsino, A., Bergami, E., Della Torre, C., Vannuccini, M.L., Addis, P., Secci, M., Dawson, K.A., Matranga, V., Corsi, I., 2017. Amino-modified polystyrene nanoparticles affect signalling pathways of the sea urchin (Paracentrotus lividus) embryos. Nanotoxicology 11, 201-209. https://doi.org/10.1080/17435390.2017.1279360

Rocha, T.L., Gomes, T., Sousa, V.S., Mestre, N.C., Bebianno, M.J., 2015. Ecotoxicological impact of engineered nanomaterials in bivalve molluscs: An overview. Mar. Environ. Res. 111, 74-88. https://doi.org/10.1016/j.marenvres.2015.06.013

Rochman, C.M., Browne, M.A., Underwood, A.J., van Franeker, J.A., Thompson, R.C., AmaralZettler, L.A., 2015. The ecological impacts of marine debris: unraveling the demonstrated evidence from what is perceived. Ecology 96, 301-312. https://doi.org/10.1890/14-2070.1

Rossi, G., Barnoud, J., Monticelli, L., 2014. Polystyrene nanoparticles perturb lipid membranes. J. Phys. Chem. Lett. 5, 241-246. https://doi.org/10.1021/jz402234c

Schiaparelli, S., Cattaneo-Vietti, R., Mierzejewski, P., 2004. A "protective shell" around the larval cocoon of Cephalodiscus densus Andersson, 1907 (Graptolithoidea, Hemichordata). Polar Biol. 27, 813-817. https://doi.org/10.1007/s00300-004-0661-x

Steele, S., Mulcahy, M.F.O., 1999. Gametogenesis of the oyster Crassostrea gigas in southern Ireland. J. Mar. Biol. Assoc. UK. 79, 673-686.

Stephens, B., Azimi, P., El Orch, Z., Ramos, T., 2013. Ultrafine particle emissions from desktop 3D printers. Atmos. Environ. 79, 334-339. https://doi.org/10.1016/j.atmosenv.2013.06.050

Sussarellu, R., Suquet, M., Thomas, Y., Lambert, C., Fabioux, C., Pernet, M.E.J., Le Goïc, N., Quillien, V., Mingant, C., Epelboin, Y., Corporeau, C., Guyomarch, J., Robbens, J., PaulPont, I., Soudant, P., Huvet, A., 2016. Oyster reproduction is affected by exposure to polystyrene microplastics. Proc. Natl. Acad. Sci. USA 201519019. https://doi.org/10.1073/pnas.1519019113

ten Brink, P., Schweitzer J-P., Watkins, E., De Smet, M., Leslie, H., Galgani, F., 2017. T20 Task 
Force Circular Economy Circular Economy Measures to Keep Plastics and Their Value in the Economy. G20 Insights, 1-12.

Ter Halle, A., Jeanneau, L., Martignac, M., Jardé, E., Pedrono, B., Brach, L., Gigault, J., 2017. Nanoplastic in the North Atlantic Subtropical Gyre. Environ. Sci. Technol. 51, 1368913697. https://doi.org/10.1021/acs.est.7b03667

Van Cauwenberghe, L., Devriese, L., Galgani, F., Robbens, J., Janssen, C.R., 2015. Microplastics in sediments: A review of techniques, occurrence and effects. Mar. Environ. Res. 111, 5-17. https://doi.org/10.1016/j.marenvres.2015.06.007

Verma, A., Stellacci, F., 2010. Effect of surface properties on nanoparticle-cell interactions. Small 6, 12-21. https://doi.org/10.1002/smll.200901158

Vignier, J., Volety, A.K., Rolton, A., Le Goïc, N., Chu, F.L.E., Robert, R., Soudant, P., 2017. Sensitivity of eastern oyster (Crassostrea virginica) spermatozoa and oocytes to dispersed oil: Cellular responses and impacts on fertilization and embryogenesis. Environ. Pollut. 225, 270-282. https://doi.org/10.1016/j.envpol.2016.11.052

Vogeler, S., Bean, T. P., Lyons, B. P., Galloway, T. S. (2016). Dynamics of nuclear receptor gene expression during Pacific oyster development. BMC Dev. Biol, 16, 33. https://doi.org/10.1186/s12861-016-0129-6

Watts, A.J.R., Urbina, M.A., Corr, S., Lewis, C., Galloway, T.S., 2015. Ingestion of Plastic Microfibers by the Crab Carcinus maenas and Its Effect on Food Consumption and Energy Balance. Environ. Sci. Technol. 49, 14597-14604. https://doi.org/10.1021/acs.est.5b04026

Wegner, A., Besseling, E., Foekema, E.M., Kamermans, P., Koelmans, A.A., 2012. Effects of nanopolystyrene on the feeding behavior of the blue mussel (Mytilus edulis L.). Environ. Toxicol. Chem. 31, 2490-2497. https://doi.org/10.1002/etc.1984

Wright, S.L., Kelly, F.J., 2017. Plastic and Human Health: A Micro Issue? Environ. Sci. Technol. 51, 6634-6647. https://doi.org/10.1021/acs.est.7b00423

Wright, S.L., Rowe, D., Thompson, R.C., Galloway, T.S., 2013. Microplastic ingestion decreases energy reserves in marine worms. Curr. Biol. 23, R1031-R1033. https://doi.org/10.1016/j.cub.2013.10.068

Xie, J., Yang, D., Sun, X., Cao, R., Chen, L., Wang, Q., Li, F., Wu, H., Ji, C., Cong, M., Zhao, J., 2017. Individual and Combined Toxicities of Benzo[a]pyrene and 2,2",4,4"Tetrabromodiphenyl Ether on Early Life Stages of the Pacific Oyster, Crassostrea gigas. Bull. Environ. Contam. Toxicol. 99, 582-588. https://doi.org/10.1007/s00128-017-2164-9 
721 Table 1. Mean size (in $\mathrm{nm}$ ), aggregation state (PDI in arbitrary units, A.U.) and charge $(\zeta$ -

722 Potential in $\mathrm{mV}$ ) of polystyrene particles in ultrapure water (UW), and UV-treated 1- $\mu \mathrm{m}$ filtered 723 seawater (FSW). Analyses were performed by Dynamic Light Scattering (DLS) at $20^{\circ} \mathrm{C}$ in 724 triplicate and data are represented as means $\pm \mathrm{SD}$. Comparisons were made between media using 725 the Student's t-test; * $\mathrm{p}<0.05, * * \mathrm{p}<0.01, * * * \mathrm{p}<0.001$

\section{Figure legends}

727 Fig. 1 Life cycle of oyster showing the results of exposures on different stages to MP/NP. This 728 scheme was modified from Vogeler et al. (2016).

729 Fig. 2 Fertilization yield (\%) after $1.5 \mathrm{~h}$ exposure of oyster gametes $\left(1,000\right.$ oocytes.mL $\mathrm{mL}^{-1} ; 100: 1$ 730 spermatozoa:oocyte ratio) to (A) $2-\mu \mathrm{m}$, (B) 500-nm, (C) Plain-50 nm, (D) COOH-50 nm, (E) $731 \mathrm{NH}_{2}-50 \mathrm{~nm}$ polystyrene beads at five concentrations: $0,0.1,1,10$ and $25 \mu \mathrm{g} / \mathrm{mL}$. The assay was 732 replicated five times and data are represented as means \pm SD. Multiple comparisons were made 733 between treatments using Tukey's HSD (500-nm, $\mathrm{NH}_{2}-50$ ) or Conover (Plain-50, $\mathrm{COOH}-50$ ) 734 methods at the 5\% alpha level; homogeneous groups are indicated by the same letter.

735 Fig. 3 D-larval yield (\%) after $36 \mathrm{~h}$ exposure of fertilized eggs to (A) 2- $\mu \mathrm{m}$, (B) 500-nm, (C) 736 Plain-50 nm, (D) $\mathrm{COOH}-50 \mathrm{~nm}$, (E) $\mathrm{NH}_{2}-50 \mathrm{~nm}$ polystyrene beads at five concentrations: 0, 0.1, 7371,10 and $25 \mu \mathrm{g} / \mathrm{mL}$. The assay was replicated five times and data are represented as mean \pm SD. 738 Multiple comparisons were made between treatments using Tukey's HSD (Plain-50, COOH-50) 739 or Conover $\left(\mathrm{NH}_{2}-50\right)$ methods at the $5 \%$ alpha level; homogeneous groups are indicated by the 740 same letter.

741 Fig. 4 Microscopy panel of embryo-larval development success after $36 \mathrm{~h}$ exposure to 742 polystyrene nanobeads compared with normal D-larvae observed in the control treatment (A), 743 larvae with shell and/or mantle malformations after exposure to Plain-50 (25 $\mu \mathrm{g} / \mathrm{mL})$ (B), and 744 COOH-50 (10 $\mu \mathrm{g} / \mathrm{mL})(\mathrm{C})$. Only developmental arrest, dead larvae and cell debris were observed for all embryos following exposure to $25 \mu \mathrm{g} / \mathrm{mL}$ of COOH-50 (D) and from 1 to $25 \mu \mathrm{g} / \mathrm{mL}$ of $\mathrm{NH}_{2}-50$ (E and F). Size in $\mu \mathrm{m}$ is represented by the scale bar. 
Table 1

\begin{tabular}{cccccc} 
Media & Particles & $\begin{array}{c}\text { Commercial } \\
\text { Size }(\mathbf{n m})\end{array}$ & $\begin{array}{c}\text { Particle/Aggregate Size } \\
(\mathbf{n m})\end{array}$ & PDI (A.U.) & $\zeta$-Potential (mV) \\
\hline \multirow{4}{*}{ UW } & $2-\mu \mathrm{m}$ & 2,000 & $2681.0 \pm 50.5$ & $0.35 \pm 0.01$ & $-44.8 \pm 0.9$ \\
& $500-\mathrm{nm}$ & 500 & $774.3 \pm 29.3$ & $0.46 \pm 0.05$ & $-67.8 \pm 7.0$ \\
& $\mathrm{COOH}-50$ & 50 & $55.9 \pm 0.4$ & $0.06 \pm 0.01$ & $-62.1 \pm 0.4$ \\
& $\mathrm{Plain}-50$ & 50 & $49 \pm 0.4$ & $0.03 \pm 0.02$ & $-70.1 \pm 1.4$ \\
& $\mathrm{NH}_{2}-50$ & 50 & $53.3 \pm 2.3$ & $0.12 \pm 0.02$ & $44.0 \pm 1.5$ \\
\hline \multirow{3}{*}{ FSW } & $2-\mu \mathrm{m}$ & 2,000 & $3113.7 \pm 32.3^{* * *}$ & $0.42 \pm 0.02$ & $-30.5 \pm 1.5^{* * *}$ \\
& $500-\mathrm{nm}$ & 500 & $1620.7 \pm 188.8^{*}$ & $0.66 \pm 0.08$ & $-28.3 \pm 0.6^{* *}$ \\
& $\mathrm{COOH}-50$ & 50 & $3735.0 \pm 443.8^{* *}$ & $0.48 \pm 0.01$ & $-13.8 \pm 0.8^{* * *}$ \\
& $\mathrm{Plain}-50$ & 50 & $5951.0 \pm 264.3^{* * *}$ & $0.60 \pm 0.05$ & $-31.3 \pm 4.4^{* *}$ \\
& $\mathrm{NH}_{2}-50$ & 50 & $96.5 \pm 2.0^{* * *}$ & $0.52 \pm 0.01$ & $15.6 \pm 2.7^{* * *}$ \\
\hline
\end{tabular}


Sussarellu et al. (2016): MP (2 and $6 \mu \mathrm{m}$; Plain) interfered with energy uptake and allocation during gametogenesis leading to decrease of reproduction health indices (quality of gametes and offspring)

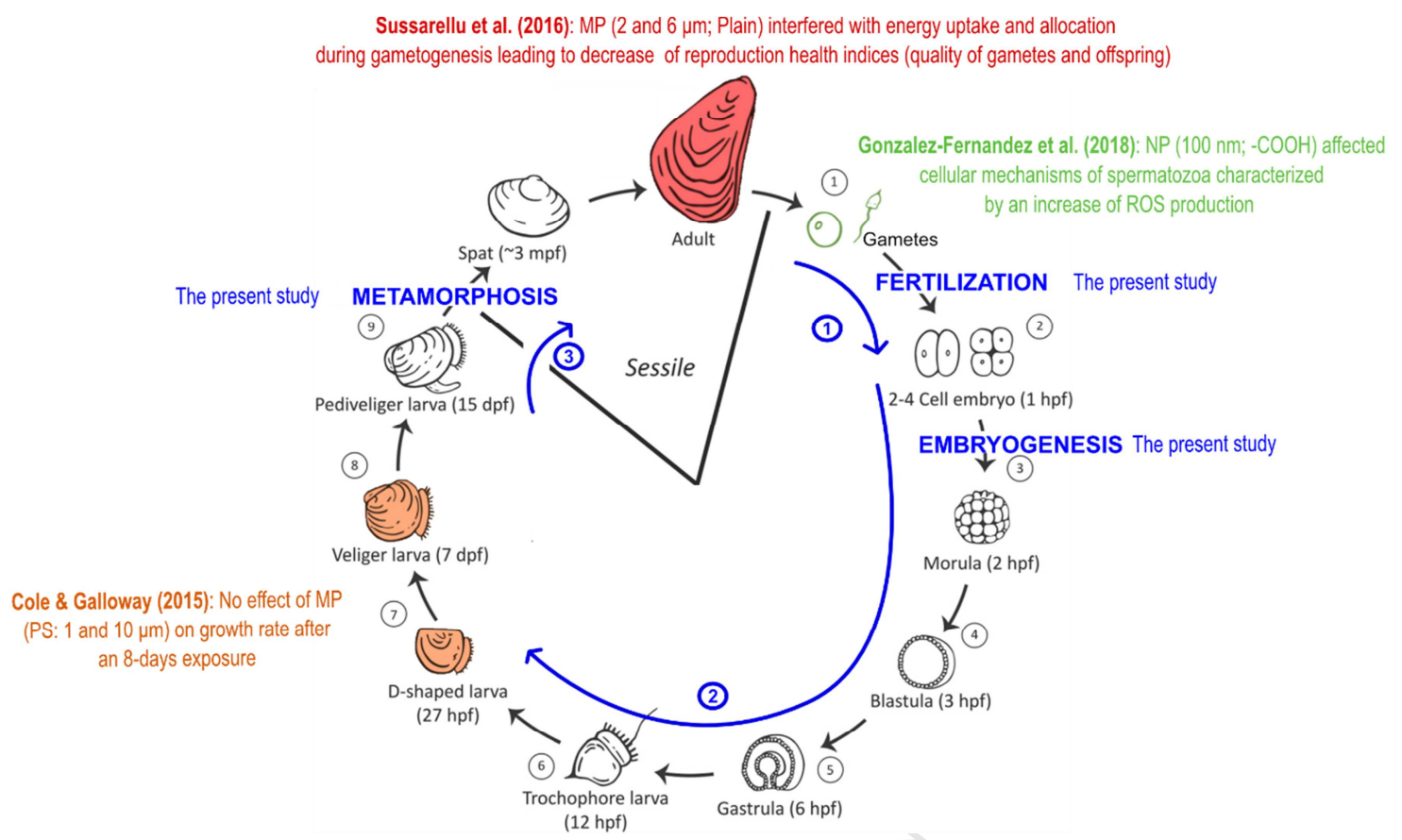

$750 \quad$ Fig. 1 
A Plain-2- $\mu$ m $\quad$ B $\quad$ Plain-500-nm $\quad$ C $\quad$ Plain-50 nm
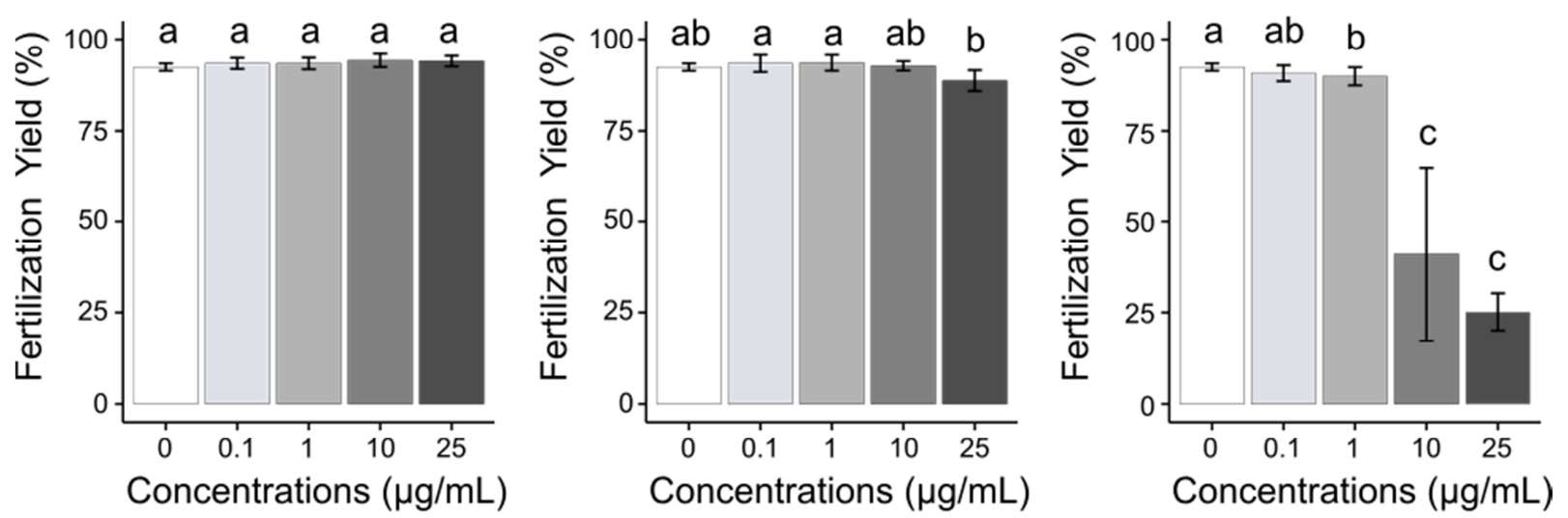

D $\mathrm{COOH}-50 \mathrm{~nm}$

E

$\mathrm{NH}_{2}-50 \mathrm{~nm}$
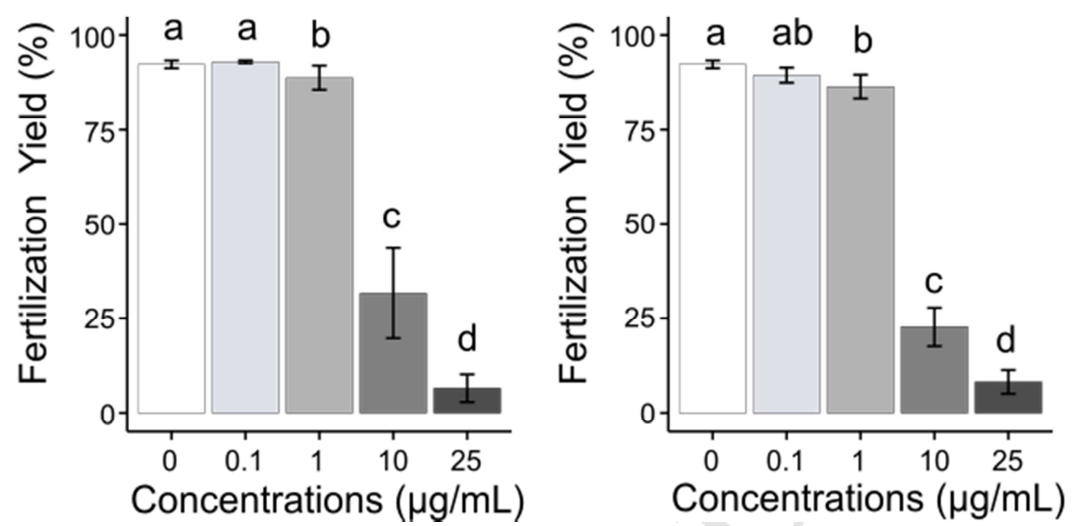

Fig. 2 
A Plain-2- $\mu \mathrm{m}$

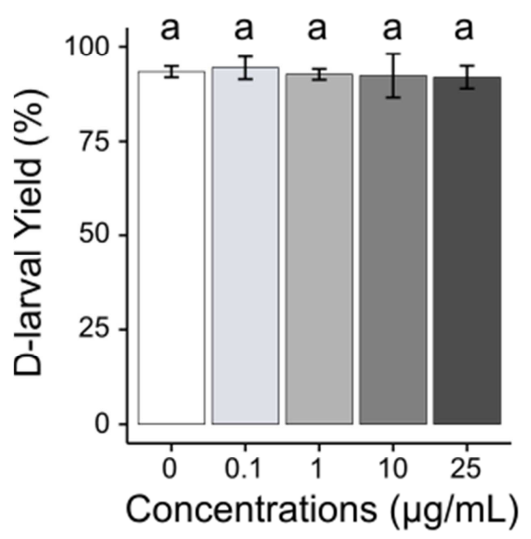

D $\mathrm{COOH}-50 \mathrm{~nm}$

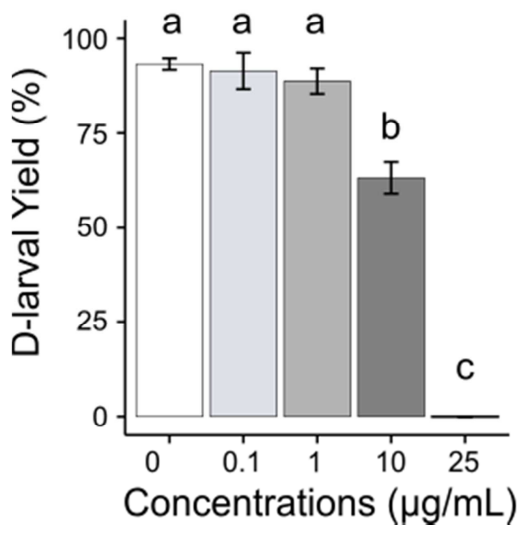

B

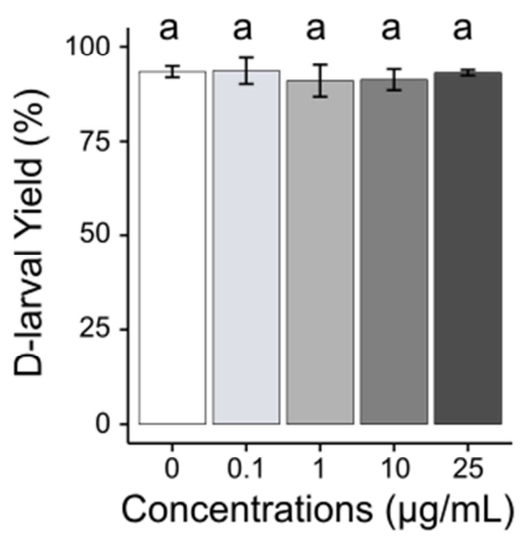

E

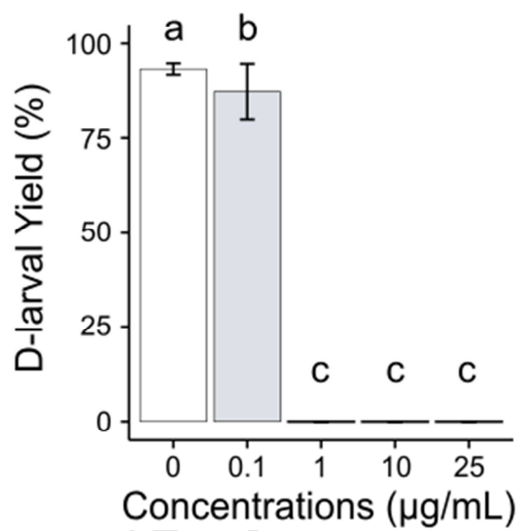

C Plain-50 nm

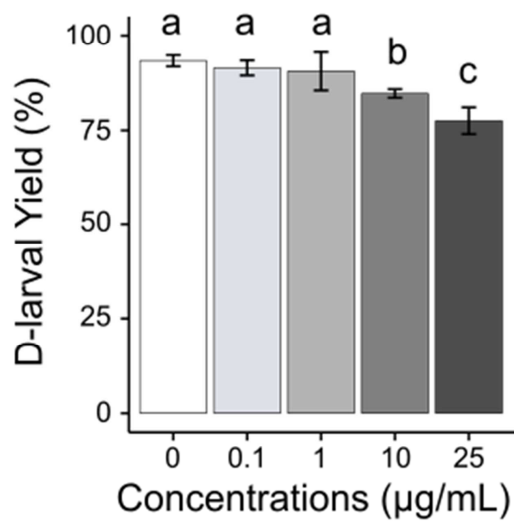

Fig. 3 


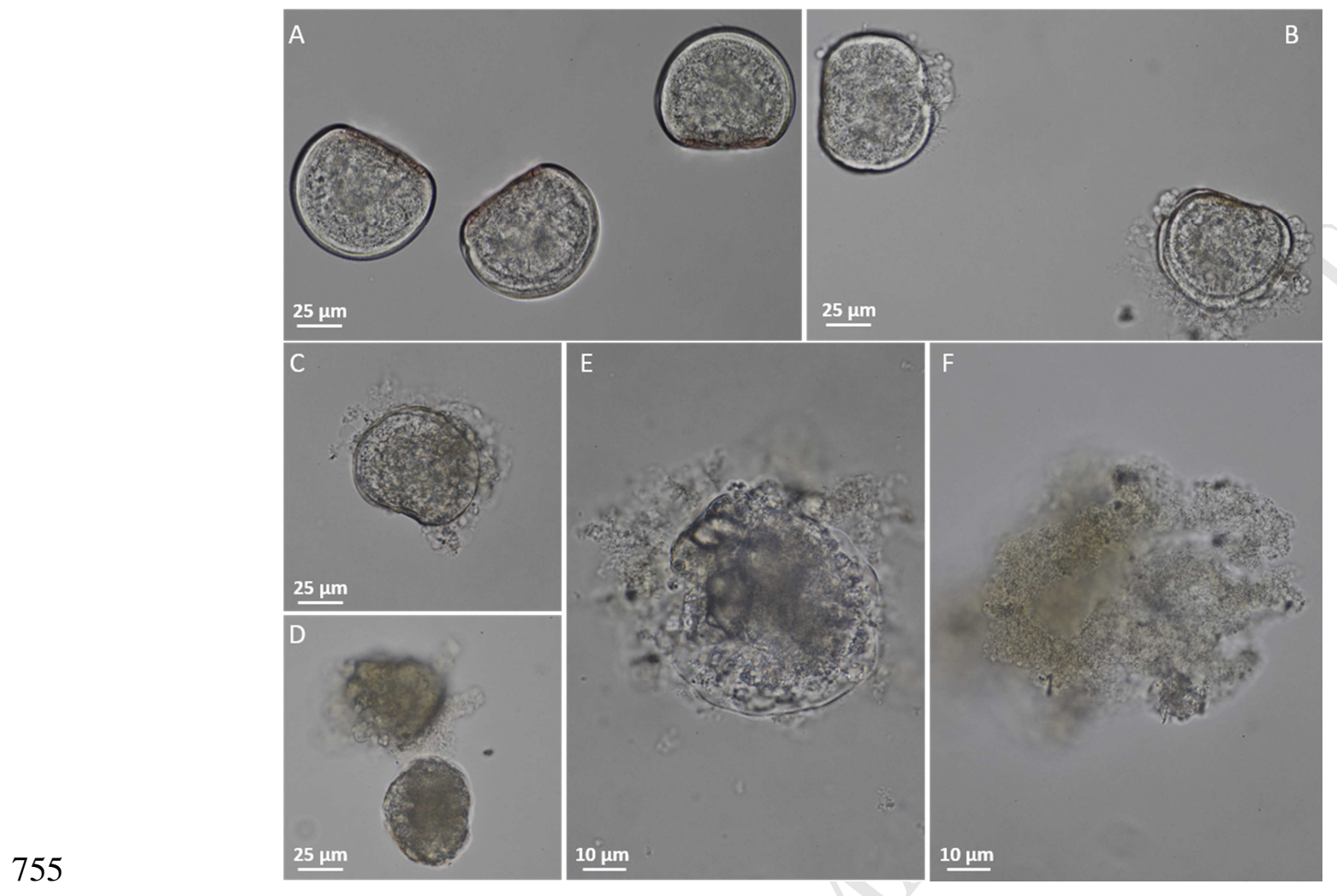

$756 \quad$ Fig. 4 